\section{Surface Roughness of Composite Resins Subjected to Hydrochloric Acid}

Ana Carolina Cabral Roque ${ }^{1}$, Lauren Oliveira Lima Bohner ${ }^{1}$, Ana Paula Terossi de Godoi ${ }^{1}$, Vivian Colucci², Silmara Aparecida Milori Corona ${ }^{2}$, Alma Blásida Concepción Elizaur Benitez Catirse ${ }^{1}$
'Department of Dental Materials and Prosthodontics, Dental School of Ribeirão Preto, USP - Universide de São Paulo, Ribeirão Preto, SP, Brazil ${ }^{2}$ Department of Restorative Dentistry, School of Dentistry of Ribeirão Preto, USP - University de São Paulo, Ribeirão Preto, SP, Brazil

Correspondence: Alma Blásida Concepción Elizaur Benitez Catirse, Avenida do Café, s/n 14040-904 Ribeirão Preto, SP, Brasil. Tel: +55-163602-4044. e-mail: alma@forp.usp.br

Key Words: dental materials, composite resins, hydrochloric acid.

\section{Introduction}

Dental erosion is one of the main factors for tooth wear (1) that occurs without bacterial involvement by chemical dissolution of the dental structure (1-3) by acids (1). These acids are derived from the dietary and endogenous factors, such as eating disorders and gastroesophageal reflux $(1,4)$.

The hydrochloric acid released by gastroesophageal reflux may be responsible for a severe tooth wear, when it remains in contact with the oral cavity for a long time (5). If tooth structure loss reaches a high severity, functional and esthetic rehabilitation of the teeth becomes indispensable (1). The choice of an adequate restorative material plays an extremely relevant role in the durability of the restoration.

Composite resin provides excellent properties for restoration, including wear resistance (6). However, dental erosion can damage the physical and mechanical properties of the composite (3), leading to organic matrix degradation and exposure of the inorganic filaments (7). These changes lead to increase of surface softening and roughness, which are responsible for the decrease in restoration durability (8).

Likewise, the resin matrix may be eroded by tooth brushing, leading to irregularities on the material's surface (9). The abrasion resulting from brushing acts synergistically with the erosion phenomenon, leading to product degradation over the course of time (3).
Recently, a composite resin containing nanofillers, which has better mechanical properties than those of microhybrid resin, was introduced on the market. The insertion of a large quantity of small, homogeneously distributed fillers provides the organic matrix greater protection against wear, thereby enhancing the material resistance to degradation (10).

It is essential to choose material suitable for restoring the teeth of patients with gastroesophageal reflux in order to ensure longevity of the procedure, because contact with hydrochloric acid may be cause for superficial alteration in composite resin. This may especially occur simultaneously with brushing. Thus, the aim of this study was to evaluate the effect of hydrochloric acid on the surface roughness of composite resins submitted to brushing. The tested null hypotheses were: 1) hydrochloric acid does not affect the surface roughness of composite resins submitted to brushing; 2) The composition of material has no influence on the wear resistance of composite resin.

\section{Material and Methods \\ Experimental Design}

The experimental design was factorial, with the evaluated factors composite resin at three levels: microhybrid composite (Z100), nanofilled composite 
(Filtek Supreme) and nanohybrid composite (Ice); and acid challenge, at two levels: absence and presence. The response variable was surface roughness $(\mu \mathrm{m})$. The materials used in this study are described in Tables 1 and 2.

\section{Specimen Preparation}

Twenty specimens of each material were prepared, totaling 60 samples. The composite resin filaments were inserted in a cylindrical stainless steel matrix with a $6 \mathrm{~mm}$ diameter and $2 \mathrm{~mm}$ deep. After the matrix was filled, a polyester strip was pressed onto the surface, by a glass slab and a $500 \mathrm{~g}$ weight. After $30 \mathrm{~s}$ the weight was removed and the composite resin was light-polymerized using a LED light-curing unit with $1200 \mathrm{~mW} / \mathrm{cm}^{2}$ power output (Dabi Atlante, Ribeirão Preto, SP, Brazil), according to the manufacturer's instructions.

The specimens were stored in $15 \mathrm{~mL}$ of artificial saliva at $37^{\circ} \mathrm{C}$ for $24 \mathrm{~h}$. The specimens were polished with SofLex discs (3M/ESPE, Sumaré, SP, Brazil) with different granulations for $20 \mathrm{~s}$ each.

\section{Acid Challenge}

For each material, half of the composite cylinders were subjected to acid challenge,which was done by immersing each specimen in $15 \mathrm{~mL}$ of hydrochloric acid (Quality Ind. Chemicals and Cleaning Ltda-EPP; pH=1.2) for 1 min, 4 times per day for 7 days. The immersion

Table 1. Composite resins utilized on this study

\begin{tabular}{|c|c|c|c|c|}
\hline $\begin{array}{l}\text { Composite } \\
\text { resin }\end{array}$ & Composition & $\begin{array}{l}\text { Particle } \\
\text { size }\end{array}$ & Shade & Manufacturer \\
\hline Z100 & $\begin{array}{l}\text { Bis-GMA and TEGDMA } \\
\text { Inorganic matrix: } \\
\text { Zirconia/silica (71\%) }\end{array}$ & $0.6 \mu \mathrm{m}$ & A2 & $\begin{array}{l}\text { 3M/ESPE, St. } \\
\text { Paul, MN, USA }\end{array}$ \\
\hline $\begin{array}{l}\text { Filtek }^{\mathrm{TM}} \\
\text { Supreme }\end{array}$ & $\begin{array}{c}\text { BIS-GMA,BIS-EMA, UDMA } \\
\text { and TEGDMA }(72.5 \%)\end{array}$ & $75 \mathrm{~nm}$ & $\mathrm{~A} 2$ & $\begin{array}{l}\text { 3M/ESPE, St. } \\
\text { Paul, MN, USA }\end{array}$ \\
\hline lce & $\begin{array}{c}61 \% \text { of inorganic matrix } \\
\text { and particles of strontium } \\
\text { aluminosilicate }\end{array}$ & $\begin{array}{c}0.01- \\
1.3 \mu \mathrm{m}\end{array}$ & $\mathrm{A} 2$ & $\begin{array}{l}\text { SDl, São } \\
\text { Paulo, SP, } \\
\text { Brazil }\end{array}$ \\
\hline
\end{tabular}

cycles were performed each day at $8 \mathrm{am}, 2 \mathrm{pm}, 6 \mathrm{pm}$ and $8 \mathrm{pm}$, according to a modification of the original protocol proposed by Honório et al. (11). Between immersions each specimen was stored in distilled water at $37^{\circ} \mathrm{C}$. The specimens not submitted to acid challenge were stored in $15 \mathrm{~mL}$ of artificial saliva at $37^{\circ} \mathrm{C}$.

\section{Abrasive Challenge}

All the specimens were subjected to abrasive challenge by a tooth brushing machine (Pepsodent - MAVTEC, Ribeirão Preto, SP, Brazil) fitted with soft toothbrushes (Condor S/A Ind. Com. Ltda., São Bento do Sul, SC, Brazil).

Brushing was performed at a speed of $356 \mathrm{rpm}$, with dentifrice slurry ratio $1: 1$ covering a $3.8 \mathrm{~cm}$ track with $200 \mathrm{~g}$ load on the specimen. The specimens were brushed for cycles with a 50 min duration each, for 7 days (17.8 cycles). The first cycle was performed after the second daily acid challenge (7).

\section{Surface Roughness Analysis}

The surface roughness analysis was performed before the experiment began (T0) and at the end of the abrasive challenges (T1). For each analysis, three roughness measurements (Ra) were taken by a rugosimeter (Mitutoyo Co, Kawasaki, Japan).

\section{Statistical Analysis}

The mean and standard deviation of roughness $(\Delta \mathrm{Ra})$ were calculated and analyzed by two-way ANOVA and Tukey tests $(p \leq 0.05)$. The calculations were performed with the GMC software (www.forp. usp.br/restauradora/gmc/gmc.html\#gmc).

\section{Results}

Surface roughness values were statistically higher for the specimens subjected to acid challenge and brushing $(1.07 \pm 0.24)$ in comparison with specimens subjected to brushing only $(0.72 \pm 0.04)$

There was significant interaction $(p<0.05)$

Table 2. Materials used in this study

\begin{tabular}{|c|c|c|}
\hline Material & Composition & Manufacturer \\
\hline Artificial saliva & $\begin{array}{l}\mathrm{Na} 2 \mathrm{HPO} 4(0.26 \mathrm{~g} / \mathrm{L}), \mathrm{NaCl}(6.7 \mathrm{~g} / \mathrm{L}), \mathrm{KSCN}(0.33 \mathrm{~g} / \mathrm{L}), \\
\mathrm{KH}_{2} \mathrm{PO}_{4}(0.2 \mathrm{~g} / \mathrm{L}), \mathrm{NaHCO}_{3}(1.5 \mathrm{~g} / \mathrm{L}), \mathrm{KCl}(1.2 \mathrm{~g} / \mathrm{L})\end{array}$ & $\begin{array}{l}\text { School of Pharmaceutical Sciences of Ribeirão } \\
\text { Preto, University of São Paulo, Brazil }\end{array}$ \\
\hline $\begin{array}{l}\text { Hydrochloric } \\
\text { acid }\end{array}$ & $30 \% \mathrm{HCl}, \mathrm{H} 20$ & $\begin{array}{l}\text { Quality Ind. Chemicals and Cleaning } \\
\text { Ldta-EPP, São Paulo, SP, Brazil }\end{array}$ \\
\hline Sof-lex disc & Mylar ${ }^{\mathrm{TM}}$ metal center, aluminum oxide & 3M/ ESPE, St. Paul, MN, USA \\
\hline Dentifrice & $\begin{array}{l}\text { Water, sorbitol, hydrated silica, sodium lauryl sulfate, PVM } \\
\text { / MA copolymer, carrageenan, sodium hydroxide, sodium } \\
\text { fluoride, triclosan, sodium saccharin, titanium dioxide }\end{array}$ & $\begin{array}{l}\text { Colgate-Palmolive Industrial } \\
\text { LTDA, São Paulo, SP, Brazil }\end{array}$ \\
\hline
\end{tabular}


between acid challenge $x$ composite resin. The microhybrid composite showed higher surface roughness than the nanofilled and nanohybrid resins for the specimens not subjected to acid challenge. However, in presence of hydrochloric acid, there was no significant difference between the microhybrid resin and the nanofilled composite, while the nanohybrid composite showed the lowest surface roughness. The means and standard deviations of surface roughness (Ra) are presented in Table 3.

\section{Discussion}

In the present study, the association between gastroesophageal reflux and brushing was simulated, whereas other external factors that could contribute to tooth and restorative material erosion were eliminated. Thus, despite the limitations of an in vitro study, this was advantageous, because it allowed control of the erosion time, $\mathrm{pH}$ and the applied erosive agents.

The first null hypothesis was rejected, since surface roughness value was higher for specimens immersed in hydrochloric acid compared with those that were not subjected to acid challenge. The main explanation for this is that restorative materials tend to undergo degradation after subjected to acid conditions (2), due to polymeric matrix wear, leading to the exposure of filaments and loss of filamentous particles (9).

In addition, abrasion plays an important role in restorative material wear $(7,18)$, causing the chemical dissolution of composite resin (7). Toothbrush abrasion modifies the balance between the organic matrix and filamentous particles, damages the bond between components, leading to loss of the inorganic portion and exposure of particles (10). Oliveira et al. (2011) showed the high surface roughness of restorative material after brushing. Moreover, studies have reported that abrasion and erosion act synergistically in restorative material wear (3). However, as the present study did not evaluate the brushing effect alone, it is not possible to affirm that brushing is responsible for material surface alterations.

With regards to the material, the second null hypothesis was rejected, since the results suggest that its composition

Table 3. Surface roughness mean and standard deviation (Ra) to composite resin $\mathrm{x}$ acid challenge

\begin{tabular}{lll}
\hline Composite resin & Absence & Presence \\
\hline Microhybrid & $1.01 \pm 0.27^{\mathrm{a}, \mathrm{A}}$ & $1.26 \pm 0.28^{\mathrm{a}, \mathrm{B}}$ \\
Nanofilled & $0.68 \pm 0.09^{\mathrm{b}, \mathrm{A}}$ & $1.18 \pm 0.30^{\mathrm{a}, \mathrm{B}}$ \\
Nanohybrid & $0.48 \pm 0.15^{\mathrm{c}, \mathrm{A}}$ & $0.77 \pm 0.15^{\mathrm{b}, \mathrm{B}}$ \\
\hline
\end{tabular}

Different lowercase letters in columns and uppercase letters in rows indicate statistically significant difference at 5\%. plays an important role in wear resistance. Since previous studies have shown that surface roughness is determined by hardness, size and quantity of filler particles immersed in the matrix $(19,20)$, it is supposed that the findings are mostly related to the inorganic components of composite resin.

Nanofilled composite showed a lower surface roughness compared with microhybrid resin. However, the composites presented similar results when immersed in hydrochloric acid. The smaller the particles, the higher will be the wear resistance of material, since it will present greater homogeneity and less prominent particles on surface (21). Thus, microhybrid composite may have undergone a higher degree of degradation by brushing due to its large particles, which protrude more easily through the surface (22). Nevertheless, acid challenge resulted in a higher wear in both composites during the first time interval, leading to fillers being pulled out and greater susceptibility to degradation by brushing.

Furthermore, the properties of composite resin will be influenced by type and volume of the filler particles (23). With regards to the volume and arrangement of inorganic particles in a composite containing a high volume of fillers, agglomeration of particles may occur with subsequent deterioration of wear resistance (24).

In the present study, the results showed that the nanohybrid composite presented the lowest surface roughness both in the absence and presence of acid challenge. As the composite has smaller volume of fillers compared with the other composites, it may be assumed that there was a uniform dispersion of particles, which leads to an improvement in composite properties.

An important factor to consider with regards to erosion is the role of saliva protecting the restorative material surfaces from erosion, since it dilutes and neutralizes the acid solution $(1,4,16)$. The specimens were stored in artificial saliva at $37{ }^{\circ} \mathrm{C}$, allowing protection of the restorative material.

The specimens were immersed in acid for 1 min during each cycle. However, saliva neutralizes the acid up to $3 \mathrm{~min}$ after its permanence in the oral cavity (3). Similarly, the 50min abrasive cycle is equivalent to 1 year of toothbrushing, considering that under clinical conditions the material would be in contact with the toothbrush for $10 \mathrm{~s}$ during each brushing session (3). Considering the short period of the acid contact with the surface of composite material in a clinical situation, the present study was designed with a long period of tooth erosion followed by brushing.

Although restorative material usually displays a greater resistance to dental erosion in comparison with the tooth (6), a short period was sufficient to change the composite resin surface. Intrinsic factors may cause dental erosion according to how frequently they will occur (17). Although 
each cycle was responsible only for a short contact between the hydrochloric acid and the composite resin, the high number of cycles was shown to play a significant role in dental erosion.

In summary, the smaller the particles, the higher will be the wear resistance of the material, since it will present greater homogeneity and less prominent particles on the surface (21). Nanotechnology allows a smaller contraction, higher resistance and less polishing (25). Thus, considering that nanohybrid composite resin has smaller particles, it might be preferable when performing procedures in patients with gastroesophageal reflux.

Within the limitations of an in vitro study, it was possible to conclude that a high frequency of exposure to hydrochloric acid promotes increase in surface roughness of composite resin subjected to brushing. Nanoparticle resins may be preferable to use in the treatment of patients with gastroesophageal reflux due to their higher wear resistance.

\section{Resumo}

Este estudo avaliou a influencia do ácido clorídrico na rugosidade superficial de resinas compostas submetidas a escovação. Sessenta corpos de prova medindo $2 \mathrm{~mm}$ de espessura $\times 6 \mathrm{~mm}$ de diâmetro foram confeccionados e utilizados como unidades experimentais. 0 presente estudo envolve uma análise fatorial $3 \times 2$, onde os fatores foram resina composta $(n=20)$, com 3 niveis: resina composta microhibrida (Z100), nanoparticulada (Filtek ${ }^{\mathrm{TM}}$ Supreme) e nanohibrida (Ice); e desafio ácido ( $n=10)$, com 2 niveis: ausência e presença. 0 desafio ácido foi realizado por meio da imersão em ácido clorídrico $(\mathrm{pH} \mathrm{1,2)}$ por $4 \mathrm{~h}$ diárias, 1 min cada imersão, durante 7 dias. Os espécimes que não foram submetidos ao desafio ácido foram armazenados em $15 \mathrm{~mL}$ de saliva artificial a $37^{\circ} \mathrm{C}$. Todos os espécimes foram submetidos ao desafio abrasivo. 0 processo de escovação foi realizado com $200 \mathrm{~g}$ de peso, com velocidade de $356 \mathrm{rpm}$, totalizando 17,8 ciclos. As medidas de rugosidade superficial $(R a)$ foram realizadas e analisadas por meio da ANOVA e teste de Tukey $(p<0,05)$. Os valores de rugosidade superficial foram maiores na presença $(1,07 \pm 0,24)$ quando comparado com a ausencia do ácido hidroclorídrico $(0,72 \pm 0,04)$. A resina microhibrida $(1,01 \pm 0,27)$ apresentou maior rugosidade superficial que as resinas nanoparticulada $(0,68 \pm 0,09)$ e nanohibrida $(0,48 \pm 0,15)$ quando os espécimes não foram submetidos ao desafio ácido. Na presença do ácido hidrocloridrico, a resina microhibrida $(1,26 \pm 0,28)$ e a resina nanoparticulada $(1,18 \pm 0,30)$ apresentou maior valor de rugosidade superficia comparado com a resina nanohíbrida $(0.77 \pm 0.15)$. 0 ácido hidrocloridrico influenciou a rugosidade superficial da resina composta submetida a escovação.

\section{Acknowledgements}

The authors are acknowledge CNPq (grant \#032/2012).

\section{References}

1. Soares $L E$, Lima LR, Vieira LS, do Espírito Santo AM, Martin AA. Erosion effects on chemical composition and morphology of dental materials and root dentin. Microsc Res Tech 2012;75:703-710.

2. Francisconi LF, Honório HM, Rios D, Magalhães AC, Machado MA, Buzalaf MA. Effect of Erosive $\mathrm{pH}$ cycling on different restorative materials and enamel restored with these materials. Oper Dent 2008;33:203-208.

3. $\mathrm{Yu} \mathrm{H}$, Wegehaupt FJ, Wiegand $\mathrm{A}$, Roos M, Attin T, Buchalla W. Erosion and abrasion of tooth-colored restorative materials and human enamel. J Dent, 2009;37:913-922.

4. Lussi A, Schueter N, Rakhmatullina E, Ganss C. Dental Erosion - An overview with emphasis on chemical and histopathological aspects. Caries Res 2011;45:2- 12.
5. Hengtrakool C, Kukiattrakoon B, Kedjarune-Leggat U. Effect of naturally acidic agents on microhardness and surface micromorphology of restorative materials. Eur J Dent 2011;5:89-100.

6. Soares LE, de Oliveira R, Nahorny S, Santo AM, Martin AA. Micro energydispersive $\mathrm{X}$-ray fluoresence mapping of enamel and dental materials after chemical erosion. Microsc Microanal 2012;18:1112-1117.

7. Correr, GM, Bruschi Alonso RC, Baratto-Filho F, Correr-Sobrinho L, Sinhoreti RA, Puppin-Rontani RM. In vitro long-term degradation of aesthetic restorative materials in food-simulating media. Acta Odontol Scand, 2012;70:101- 108.

8. Uppal M, Ganesh A, Balagopal S, Kaur G. Profilometric analysis of two composite resins' surface repolished after tooth brush abrasion with three polishing systems. J Conserv Dent 2013;16:309-313.

9. Trauth KGS, Godoi APT, Colucci V, Corona SA, Catirse AB. The influence of mouthrinses and simulated toothbrushing on the surface roughness of a nanofilled composite resin. Braz Oral Res 2012;26:209-214.

10. Oliveira GU, Mondelli RFL, Rodrigues MC, Franco EB, Ishikiriama SK, Wang L. Impact of filler size and distribution on roughness and wear of composite resin after simulated toothbrushing. J Appl Oral Sci 2012;20:510-516.

11. Honório $H M$, Rios $D$, Francisconi $L F$, Magalhães $A C$, Machado $M A$, Buzalaf MA. Effect of prolonged erosive $\mathrm{pH}$ cycling on different restorative materials. J Oral Rehabil 2008;35:947- 953.

12. Almeida e Silva JS, Baratieri LN, Araujo E, Widmer N. Dental erosion: understanding this pervasive condition. J Esthet Restor Dent 2011;23:205-216.

13. Barron RP, Carmichael RP, Marcon MA, Sandor GK. Dental erosion in gastroesophageal reflux disease. J Can Dent Assoc 2003;69:84-89.

14. Delaviz Y, Finer Y, Santerre JP. Biodegradation of resin composites and adhesives by oral bacteria and saliva: A rationale for new material designs that consider the clinical environment and treatment challenges. Dent Mater 2014;30:16-32.

15. Yu $H$, Buchalla $W$, Cheng $H$, Wiegand A, Attin T. Topical fluoride application is able to reduce acid susceptibility of restorative materials. Dent Mater 2012;31:433-442.

16. Domiciano SJ, Colucci V, Serra MC. Effect of two restorative materials on root dentine erosion. J Biomed Mater Res B Appl Biomater 2010;93:304308.

17. Aguiar YPC, dos Santos FG, Moura EFF, da Costa FCM, Auad SM, de Paiva SM. et al. Association between dental erosion and diet in Brazilian adolescents aged from 15 to 19: A population based study. Sci World Journal 2014; 818167:1-7.

18. Pisani MX, Bruhn JP, Paranhos HFO, Silva-Lovato $\mathrm{CH}_{\text {, de Souza RF, }}$ Panzeri H. Evaluation of the abrasiveness of dentifrices for complete dentures. J Prosthodont 2010;19:369- 373.

19. Attar, N. The effect of finishing and polishing procedures on the surface roughness of composite resin materials. J Contemp Dent Pract 2007;8:27-35.

20. Dos Santos PH, Pavan S, Consani S, Sobrinho LC, Sinhoreti AS, Filho JN. In vitro evaluation of surface roughness of 4 resin composites after the toothbrushing process and methods to recover superficial smoothness. Quintessence Int 2007;38:247-253

21. Antonson SA, Yazici AR, Okte Z, Villata P, Andonson DE, Hardigan PC. Effect of resealing on microleakage of resin composite restorations in relationship to margin design and composite type. Eur J Dent 2012:6:389-395.

22. Turssi $\mathrm{CP}$, Ferracane $\mathrm{JL}$, Vogel $\mathrm{K}$. Filler features and their effects on wear and degree of conversion of particulate dental resin composites. Biomat 2005;26:4932-4937

23. Mandikos MN, Mcgivney GP, Davis E, Bush PJ, Carter JM. A comparison of the wear resistance and hardness of indirect composite resins. J Prosthet Dent 2001;85:386-395.

24. Friedrich $K$, Zhang Z, Schlarb A. Effects of various fillers on the sliding wear of polymer composites. Compos Sci Technol 2005,65:2329-2343.

25. Shaw L, O'Sullivan E. Diagnosis and prevention of dental erosion in children. Int J Paediatr Dent 2000;10:356-365. 